\title{
IN VITRO ACTIVITY OF ESSENTIAL OILS OF Lippia sidoides AND Lippia gracilis AND THEIR MAJOR CHEMICAL COMPONENTS AGAINST Thielaviopsis paradoxa, CAUSAL AGENT OF STEM BLEEDING IN COCONUT PALMS
}

\author{
Rejane Rodrigues da Costa e Carvalho*, Delson Laranjeira e José Luiz Sandes de Carvalho Filho \\ Departamento de Agricultura, Universidade Federal Rural de Pernambuco, Rua Dom Manoel de Medeiros, s/n, 2171-900 Recife \\ - PE, Brasil \\ Paulo Estevão de Souza \\ Departamento de Fitopatologia, Universidade Federal de Lavras, CP 3037, 37200-000 Lavras - MG, Brasil \\ Arie Fitzgerald Blank, Péricles Barreto Alves e Hugo Cesar Ramos de Jesus \\ Departamento de Agronomia e Departamento de Química, Universidade Federal de Sergipe, 49100-000 São Cristóvão - SE, Brasil \\ Dulce Regina Nunes Warwick \\ Embrapa Tabuleiros Costeiros, 49001-970 Aracaju - SE, Brasil
}

Recebido em 13/4/12; aceito em 27/8/12; publicado na web em 1/2/2013

\begin{abstract}
Essential oils of Lippia sidoides, Lippia gracilis and their main chemical components were investigated for in vitro control of Thielaviopsis paradoxa. Mycelial growth and a number of pathogen conidia were inhibited by the essential oil of $L$. sidoides at all concentrations tested $\left(0.2 ; 0.5 ; 1.0 ; 3.0 \mu \mathrm{L} \mathrm{mL}^{-1}\right)$. L. sidoides oil contained $42.33 \%$ thymol and $4.56 \%$ carvacrol, while $L$. gracilis oil contained $10 \%$ thymol and $41.7 \%$ carvacrol. Mycelial growth and conidial production of T. paradoxa were completely inhibited by thymol at a $0.3 \mu \mathrm{L} \mathrm{m}^{-1}$ concentration. The results suggest that thymol could potentially be used for controlling coconut stem bleeding.
\end{abstract}

Keywords: coconut; Lippia; Thielaviopsis paradoxa.

\section{INTRODUCTION}

In Brazil, coconut crops can be infected by several pathogens that cause many diseases. Coconut stem bleeding, caused by the fungus Thielaviopsis paradoxa, is the main concern of producers, researchers, and monitoring agencies, due to its rapid spread. In addition, no methods are currently available for disease control. The main stem-bleeding symptoms are reddish-brown liquid in the stem cracks, which may turn blackish when dried; reduced frequency of leaf emergence; reduced size of young leaves; stem thinning near the canopy as disease progresses; and brownish-yellow, easily breakable leaves. ${ }^{1}$

Worldwide awareness of environmental damage caused by pesticides has driven the search for new measures to protect plants against diseases. Alternative control methods that can be used in an integrated manner to reduce the environmental impact of chemicals, ${ }^{2}$ benefit both organic producers, who need more choices of products, and a large segment of consumers willing to pay for pesticide-free food.

Research has shown that crude extracts or essential oils of medicinal plants have great potential for pathogen control, either by direct toxic action, inhibiting mycelial growth and spore germination, or by induction of phytoalexins, which indicate the presence of compounds with characteristics of elicitors. ${ }^{3}$ Exploring the biological activity of secondary compounds of crude extracts or essential oils of medicinal plants could represent a potential form of alternative disease control in cultivated plants, along with induced resistance. ${ }^{4}$

Literature has reported the efficacy of essential oils from a wide range of plant species for promoting growth inhibition of many fungal pathogens, ${ }^{5}$ and also acting as acaricides. ${ }^{6}$ Antimicrobial activity exerted by these oils has been attributed to small terpenoids and phenolic compounds such as thymol, carvone, carvacrol, menthol, and murolene, which also act against fungal pathogens in pure form. ${ }^{\text {? }}$

*e-mail: rejanercosta@yahoo.com.br
The family Verbenaceae comprises nearly 175 genera. Among the 2300 species found in tropical and subtropical regions, the generic taxon Lippia is represented by approximately 200 species. Species of this genus are characterized by aromatic essential oils with antimicrobial activity and compounds such as thymol and carvacrol. Souza Jr. et al. ${ }^{8}$ used the essential oil of L. sidoides to control Colletotrichum gloeosporioides isolated from the passion fruit tree, obtaining $100 \%$ inhibition of mycelial growth. However, Brazilian flora has not yet been sufficiently studied. In addition, a number of isolated secondary compounds, whose chemical structure has been determined, have not yet been analyzed for biological activity. Thus, there is a need for more advanced research to find chemical compounds capable of controlling the development of plant pathogens.

We evaluated the direct effect of essential oils of $L$. sidoides Cham (popularly known as "alecrim-pimenta") and L. gracilis Schauer ("alecrim-da-chapada"), and their major components on mycelial growth and amount of spores produced by $T$. paradoxa.

\section{EXPERIMENTAL}

The experiments were conducted at the Laboratory of Plant Pathology, Embrapa Tabuleiros Costeiros and at the Laboratory of Chemistry, Federal University of Sergipe.

\section{Isolation and maintenance of the pathogen}

The fungus T. paradoxa was isolated from secondary roots and coconut strains showing typical symptoms of stem bleeding. Roots were surface-disinfected with $70 \%$ alcohol for $30 \mathrm{~s}$ and rinsed three times in sterile distilled water. The tissue pieces were then transferred to Petri dishes containing PDA medium (Potato dextrose agar) and subsequently incubated at $22{ }^{\circ} \mathrm{C}$ for 7 days. After this period, mycelial discs were removed from the edges of colonies and transferred to dishes containing PDA medium, where monospore cultures were performed. 
Colonies of T. paradoxa grown in tubes containing PDA medium were overlaid with mineral oil and maintained at $4{ }^{\circ} \mathrm{C}$.

\section{Essential oil extraction process}

Oil was extracted from $L$. sidoides and $L$. gracilis obtained at the Germplasm Bank of the Federal University of Sergipe (UFS). Leaves underwent forced air oven-drying to constant weight at $40^{\circ} \mathrm{C}$. Subsequently, $1 \mathrm{~L}$ of distilled water was added to $100 \mathrm{~g}$ of previously dried leaves and the essential oil was extracted by hydrodistillation with a Clevenger-type apparatus, ${ }^{9}$ coupled to a 3 L glass flask, for $160 \mathrm{~min}$. The essential oil was removed with a micropipette, stored in an amber glass vial wrapped with aluminum foil, and kept under refrigeration.

\section{Antifungal potential of essential oils}

The experiments were done using $0.2,0.5,1.0$, and $3.0 \mu \mathrm{L} \mathrm{mL}^{-1}$ concentrations of essential oil of $L$. sidoides and $L$. gracilis in PDA culture medium. Control treatment was the fungal disk grown on PDA. Three replicates were applied per treatment.

Thus, the essential oil was first added to melted PDA medium at a maximum temperature of $45^{\circ} \mathrm{C}$ and then poured into $9 \mathrm{~cm}$ Petri dishes. Each dish center was inoculated with a $5 \mathrm{~mm}$ diameter disk containing mycelium of the monospore culture. Dishes were incubated at $28^{\circ} \mathrm{C}$ under a $12-\mathrm{h}$ photoperiod. Evaluations were performed at the same time every day by measuring colony diameter in two orthogonal axes (average of two diametrically opposed measurements) starting $24 \mathrm{~h}$ after dish preparation until one of the treatments reached the total diameter of Petri dish.

The percentage inhibition of fungal growth (PIC) compared to control treatment was calculated using the formula:

$\mathrm{PIC}=\frac{(\text { diameter of control treatment }- \text { diameter of treatment })}{\text { diameter of control treatment }} \times 100$

Data was submitted to analysis of variance (ANOVA) and means compared by the Scott-Knott test at $5 \%$ probability.

\section{Production of conidia}

A $10 \mathrm{~mL}$ volume of distilled water plus $1 \%$ Tween 20 was added to each dish. The colony surface was scraped with a Drigalski spatula. Spores from each plate were filtered through gauze and suspended in $100 \mathrm{~mL}$ water. Three $0.1 \mathrm{~mL}$ aliquots were transferred separately from each spore suspension to a Newbauer chamber, where spores were counted with an optical microscope. Average values of the three counts were converted into number of conidia per $\mathrm{cm}^{2}$ in the colony, considering the amount of conidia produced in the area taken by the colony on each dish.

Data was submitted to ANOVA and means were compared by the Scott-Knott test at $5 \%$ probability.

\section{Gas chromatography-mass spectrometry (GC-MS)}

Qualitative analysis of the chemical composition of the essential oil was performed by a gas chromatograph coupled to a mass spectrometer GC-MS (Shimadzu QP 5050A model) fitted with a AOC-20i auto injector (Shimadzu), and DB-5MS fused silica capillary column (5\%-phenyl; 95\% dimethylpolysiloxane) $30 \mathrm{~m}$ x $0.25 \mathrm{~mm}$ ID, 0.25 $\mu \mathrm{m}$ film, using helium as the carrier gas at a flow rate of $1.2 \mathrm{~mL} /$ min. Temperature was programmed to remain at $50{ }^{\circ} \mathrm{C}$ for $1.5 \mathrm{~min}$, followed by an increase of $4{ }^{\circ} \mathrm{C} / \mathrm{min}$ until $200{ }^{\circ} \mathrm{C}$ was reached, and then at $10{ }^{\circ} \mathrm{C} / \mathrm{min}$ up to $280^{\circ} \mathrm{C}$, which was kept constant for $5 \mathrm{~min}$. Injector temperature was $250{ }^{\circ} \mathrm{C}$ and detector temperature $280{ }^{\circ} \mathrm{C}$. A $0.5 \mu \mathrm{L}$ sample was injected into ethyl acetate, and the partition ratio of volume injected was $1: 83$, and the column was $64.20 \mathrm{kPa}$. Mass spectrometer conditions were an ion capture detector operating by electric impact and impact energy of $70 \mathrm{eV}$; scan speed of 1000; scan interval of 0.50 fragments and fragments detected in the range 40-500 Da.

\section{Gas chromatography - flame ionization detector (GC-FID)}

Quantitative analysis of components was performed with a gas chromatograph equipped with a flame ionization detector (FID) Shimadzu GC-17A under the following operating conditions: ZB5MS fused silica capillary column (5\% dimethylpolysiloxane) with $30 \mathrm{~m} \times 0.25 \mathrm{~mm}$ ID $\times 0.25 \mu \mathrm{m}$ film, under the same conditions as GC-MS. Quantification of the components was performed by area normatization (\%), while concentrations were calculated based on the area and arranged in order of elution in gas chromatography.

\section{Identification of oil components}

Oil components were identified by comparing their mass spectra with spectra found in the literature,${ }^{10}$ as well as with database spectra (NIST21 and NIST107) of the equipment, and also by comparison of retention rates with those found in the literature. Relative retention indices (IRR) were determined with homologous series of n-alkanes (C9-C19) injected under the same chromatographic conditions as the samples, using the Van den Dool and Kratz equation. ${ }^{11}$

\section{Antifungal potential of the main oil components}

Antifungal potential of the main components of $L$. sidoides oil was evaluated at $0.05,0.1,0.2,0.3$, and $0.5 \mu \mathrm{L} \mathrm{mL}^{-1}$ concentrations using the same methodology described in the test with essential oils.

\section{RESULTS AND DISCUSSION}

The yield of essential oils of $L$. sidoides and L. gracilis were 5.27 and $4.82 \mathrm{~mL} \mathrm{plant}^{-1}$, respectively. All concentrations of essential oil of L. sidoides inhibited the development of pathogen T. paradoxa, corresponding to $100 \%$ percentage of mycelial growth inhibition (Table 1). Oliveira et al. ${ }^{12}$ assessed the control of mycelial growth of fungal contaminants on laboratory media using essential oils of $L$. sidoides, L. gracilis, and fungicide Carbendazin. The authors concluded that L. sidoides oil and Carbendazin were effective in inhibiting mycelial growth in all experiments.

In our study there was no inhibition of mycelial growth by the essential oil of L. gracilis (Table 1). However, existing literature reports a large number of studies on fungi toxicity of $L$. gracilis to different pathogens. In vitro studies by Albuquerque et al. ${ }^{13}$ evaluated the antimicrobial effect of essential oil of $L$. gracilis on fungal contaminants on laboratory media. The authors found that Geotrichum candidum, Trichoderma viride, Torula herbarum, Paecillomyces sp., P. aeruginens, Aspergillus nidulans, A. flavus, and Fusiococcum sp. were fully inhibited by the minimum concentration of $420 \mathrm{ppm}$ crude oil.

A large number of spores was produced by the pathogen with the oil from L. gracilis, and the concentration of $1 \mu \mathrm{L} \mathrm{mL}^{-1}$ led to the production of the highest number $\left(9.7 \times 10^{5}\right.$ spores. $\left.\mathrm{mL}^{-1}\right)$, approximately the number of spores produced by the pathogen in the control treatment $\left(1.0 \times 10^{6}\right.$ spores. $\left.\mathrm{mL}^{-1}\right)$ (Table 1$)$.

Although mechanisms of action of essential oils have been poorly characterized, they are probably associated with the lipophilic nature 
Table 1. Percentage of mycelial growth inhibition (PIC) and number of conidia (NC) produced by Thielaviopsis paradoxa under different concentrations of essential oils of Lippia species*

\begin{tabular}{lcccccc}
\hline Essential oil & $\begin{array}{c}\text { Concentration } \\
\left(\mu \mathrm{L} \mathrm{mL}^{-1}\right)\end{array}$ & $\mathrm{PIC}^{1}$ & \multicolumn{2}{c}{$\begin{array}{c}\mathrm{NC}^{2} \\
\left(\text { spores } \mathrm{mL}^{-1}\right)\end{array}$} \\
\hline Lippia sidoides & 0.2 & $100 \mathrm{a}$ & 0 & $\mathrm{a}$ & \\
Lippia sidoides & 0,5 & $100 \mathrm{a}$ & 0 & $\mathrm{a}$ & \\
Lippia sidoides & 1.0 & $100 \mathrm{a}$ & 0 & $\mathrm{a}$ & \\
Lippia sidoides & 3.0 & $100 \mathrm{a}$ & & 0 & $\mathrm{a}$ & \\
Lippia gracilis & 0.2 & 0 & $\mathrm{~b}$ & $9.2 \times 10^{5}$ & $\mathrm{c}$ \\
Lippia gracilis & 0.5 & 0 & $\mathrm{~b}$ & $8.9 \times 10^{5}$ & $\mathrm{c}$ & \\
Lippia gracilis & 1.0 & 0 & $\mathrm{~b}$ & $9.7 \times 10^{5}$ & $\mathrm{~d}$ \\
Lippia gracilis & 3.0 & 0 & $\mathrm{~b}$ & $7.9 \times 10^{5}$ & $\mathrm{~b}$ \\
Control (PDA) & 0.0 & 0 & $\mathrm{~b}$ & $1.0 \times 10^{6}$ & $\mathrm{~d}$ \\
General Mean & & 44.65 & & $5.1 \times 10^{6}$ & \\
CV(\%)** & & 1.46 & & $9.1 \times 10^{5}$ & \\
\hline
\end{tabular}

*Means followed by same letter in columns do not differ by Scott-Knott test at $5 \%$ probability. $* * \mathrm{CV}$ : Coefficient of variation. ${ }^{1,2}$ Standard deviation: $\mathrm{PIC}=0.38$ and $\mathrm{NC}=2.68$.

of the components, with membrane accumulation and energy loss by microbial cells. ${ }^{714}$ According to Piper et al. ${ }^{15}$ certain terpenes of essential oils are able to make fungal cell membrane permeable, thus causing leakage of contents.

Table 2. Percentage of chemical components of essential oils obtained in leaves of Lippia sidoides and Lippia gracilis

\begin{tabular}{|c|c|c|c|}
\hline RI & Compound & $\begin{array}{c}\text { Lippia sidoides } \\
(\%)\end{array}$ & $\begin{array}{c}\text { Lippia gracilis } \\
(\%)\end{array}$ \\
\hline 930 & $\alpha$-thujene & 0.97 & 1.19 \\
\hline 939 & $\alpha$-pinene & 0.57 & 0.50 \\
\hline 954 & camphene & 0.27 & - \\
\hline 979 & $\beta$-pinene & 0.30 & 0.19 \\
\hline 990 & myrcene & 2.85 & 3.14 \\
\hline 1002 & $\alpha$-felandrene & - & 0.19 \\
\hline 1017 & $\alpha$-erpinene & - & 2.41 \\
\hline 1017 & $\alpha$-terpinene & 1.38 & \\
\hline 1024 & p-cymene & 11.97 & 16.24 \\
\hline 1029 & limonene & 0.42 & 0.41 \\
\hline 1031 & 1.8 cineole & 3.80 & 2.78 \\
\hline 1059 & $\gamma$-terpinene & 5.44 & 12.13 \\
\hline 1096 & linalool & 0.51 & 0.53 \\
\hline 1096 & borneol & 0.37 & \\
\hline 1177 & terpinen-4-ol & 0.74 & 0.75 \\
\hline 1188 & $\alpha$-terpineol & 0.39 & 0.24 \\
\hline 1235 & methyl thymol & 9.35 & 6.06 \\
\hline 1290 & thymol & 42.33 & 18.00 \\
\hline 1299 & carvacrol & 4.56 & 27.59 \\
\hline 1419 & $\beta$-caryophyllene & 11.03 & 5.15 \\
\hline 1434 & $\alpha$-trans-bergamotene & 0.25 & 0.23 \\
\hline 1441 & aromadendrene & 0.40 & 0.24 \\
\hline 1454 & $\alpha$-humulene & 0.58 & 0.35 \\
\hline 1496 & viridiflorene & 0.51 & 0.28 \\
\hline 1578 & spathulenol & - & 0.30 \\
\hline 1583 & caryophyllene oxide & 0.74 & 0.67 \\
\hline 1592 & viridiflorol & 0.24 & 0.19 \\
\hline
\end{tabular}

RI: Relative retention rate calculated by the van den Dool equation. \%: Percentage of components. Components are listed in increasing order of elution in column DB-5MS.
Through identification of chemical components of essential oils, it was clear that there are two major chemical components in the genus Lippia, namely, thymol and carvacrol. L. sidoides oil contained $42.33 \%$ thymol and $4.56 \%$ carvacrol, whereas L. gracilis oil had $18 \%$ thymol and $27.59 \%$ carvacrol (Table 2). However, Albuquerque et al. ${ }^{16}$ found $10 \%$ thymol and $41.7 \%$ carvacrol in L. gracilis oil.

Promising results were obtained in the evaluation of the antifungal potential of the main components of $L$. sidoides oil. A Thymol concentration of $0.3 \mu \mathrm{L} \mathrm{mL}^{-1}$ promoted $100 \%$ inhibition of mycelial growth and lack of conidia of T. paradoxa in PDA culture medium. However, even at high concentrations in oil, the compounds carvacrol $(4.56 \%)$, p-cymene (11.97\%), 1.8 cineole (3.8\%), $\alpha$-terpinene $(5.44 \%)$ and $\beta$-caryophyllene $(11.03 \%)$ were unable to control the pathogen in vitro at the concentrations applied (Table 3 ).

Montanari et al. ${ }^{16}$ investigated the chemical composition and antibacterial activity of volatile oils from the leaves of Verbenaceae species Aloysia virgata, Lantana camara, Lantana trifolia, Lantana montevidensis, L. brasiliensis and L. sericea. The authors

Table 3. Percentage inhibition of mycelial growth (PIC) and number of conidia (NC) produced by Thielaviopsis paradoxa under different concentrations of chemical components thymol, carvacrol, p-cymene, 1.8 cineole, $\alpha$-terpinene and $\beta$-caryophyllene

\begin{tabular}{|c|c|c|c|c|c|c|c|}
\hline $\begin{array}{l}\text { Chemical } \\
\text { Components }\end{array}$ & $\begin{array}{c}\text { Concentration } \\
\left(\mu \mathrm{LL} \mathrm{m}^{-1}\right)\end{array}$ & & $\mathrm{IC}^{1}(\%)$ & & $\begin{array}{r}\mathrm{NC}^{2} \\
\text { (spores } \mathrm{n}\end{array}$ & $\left.n L^{-1}\right)$ & \\
\hline Thymol & 0.05 & 31.95 & $\mathrm{~d}$ & $\mathrm{~d}$ & $1.86 \times 10^{5}$ & $\mathrm{~b}$ & \\
\hline Thymol & 0.10 & 75.28 & $\mathrm{c}$ & & $5.44 \times 10^{5}$ & & \\
\hline Thymol & 0.20 & 89.72 & $\mathrm{~b}$ & & $3.38 \times 10^{5}$ & & \\
\hline Thymol & 0.30 & 100.00 & $\mathrm{a}$ & & 0.00 & & \\
\hline Thymol & 0.50 & 100.00 & $\mathrm{a}$ & & 0.00 & & \\
\hline Carvacrol & 0.05 & 0.00 & & e & $6.78 \times 10^{6}$ & & d \\
\hline Carvacrol & 0.10 & 0.00 & & $\mathrm{e}$ & $7.53 \times 10^{6}$ & & d \\
\hline Carvacrol & 0.20 & 0.00 & & $\mathrm{e}$ & $5.48 \times 10^{6}$ & $\mathrm{c}$ & \\
\hline Carvacrol & 0.30 & 0.00 & & $\mathrm{e}$ & $5.72 \times 10^{6}$ & $\mathrm{c}$ & \\
\hline Carvacrol & 0.50 & 0.00 & & $\mathrm{e}$ & $5.06 \times 10^{6}$ & $\mathrm{c}$ & \\
\hline p- cymene & 0.05 & 0.00 & & e & $5.79 \times 10^{6}$ & $\mathrm{c}$ & \\
\hline p- cymene & 0.10 & 0.00 & & $\mathrm{e}$ & $6.94 \times 10^{6}$ & & d \\
\hline p- cymene & 0.20 & 0.00 & & $\mathrm{e}$ & $6.23 \times 10^{6}$ & $\mathrm{c}$ & \\
\hline p- cymene & 0.30 & 0.00 & & $\mathrm{e}$ & $5.81 \times 10^{6}$ & $\mathrm{c}$ & \\
\hline p- cymene & 0.50 & 0.00 & & e & $6.01 \times 10^{6}$ & $\mathrm{c}$ & \\
\hline 1.8 cineole & 0.05 & 0.00 & & e & $5.86 \times 10^{6}$ & c & \\
\hline 1.8 cineole & 0.10 & 0.00 & & e & $6.25 \times 10^{6}$ & $\mathrm{c}$ & \\
\hline 1.8 cineole & 0.20 & 0.00 & & $\mathrm{e}$ & $6.71 \times 10^{6}$ & & d \\
\hline 1.8 cineole & 0.30 & 0.00 & & $\mathrm{e}$ & $7.01 \times 10^{6}$ & & d \\
\hline 1.8 cineole & 0.50 & 0.00 & & $\mathrm{e}$ & $8.01 \times 10^{6}$ & & d \\
\hline$\alpha$-terpinene & 0.05 & 0.00 & & $\mathrm{e}$ & $6.66 \times 10^{6}$ & & d \\
\hline$\alpha$-terpinene & 0.10 & 0.00 & & $\mathrm{e}$ & $7.21 \times 10^{6}$ & & $d$ \\
\hline$\alpha$-terpinene & 0.20 & 0.00 & & e & $7.53 \times 10^{6}$ & & d \\
\hline$\alpha$-terpinene & 0.30 & 0.00 & & $\mathrm{e}$ & $7.11 \times 10^{6}$ & & d \\
\hline$\alpha$-terpinene & 0.50 & 0.00 & & $\mathrm{e}$ & $6.67 \times 10^{6}$ & & d \\
\hline$\beta$-caryophyllene & 0.05 & 0.00 & & $\mathrm{e}$ & $6.15 \times 10^{6}$ & $\mathrm{c}$ & \\
\hline$\beta$-caryophyllene & 0.10 & 0.00 & & e & $6.08 \times 10^{6}$ & c & \\
\hline$\beta$-caryophyllene & 0.20 & 0.00 & & $\mathrm{e}$ & $7.28 \times 10^{6}$ & & d \\
\hline$\beta$-caryophyllene & 0.30 & 0.00 & & $\mathrm{e}$ & $5.48 \times 10^{6}$ & $\mathrm{c}$ & \\
\hline$\beta$-caryophyllene & 0.50 & 0.00 & & $\mathrm{e}$ & $5.74 \times 10^{6}$ & $\mathrm{c}$ & \\
\hline Control treatment & - & 0.00 & & $\mathrm{e}$ & $7.84 \times 10^{6}$ & & d \\
\hline$* \mathrm{CV}(\%)$ & & 2.64 & & & 25.67 & & \\
\hline
\end{tabular}

Means followed by same letter in columns do not differ by Scott-Knott test at $5 \%$ probability. ${ }^{*} \mathrm{CV}$ : Coefficient of variation. ${ }^{1,2}$ Standard deviation: $\mathrm{PIC}=0.28$ and $\mathrm{NC}=5.26$. 
demonstrated the promising possibility of using of the essential oils from A. virgata, L. brasiliensis, L. montevidensis and L. trifolia as an alternative to some disinfectants and preservatives against Grampositive and Gram-negative bacteria.

The results indicated that both essential oil of $L$. sidoides at a concentration of $0.2 \mu \mathrm{L} \mathrm{mL}^{-1}$ and its major component thymol at a 0.3 $\mu \mathrm{L} \mathrm{mL}{ }^{-1}$ concentration were effective for in vitro control of $T$. paradoxa. However, in spite of the inability of the compounds p-cymene, 1.8 cineole, -terpinene and -caryophyllene to control the pathogen when tested alone, they could be acting in synergy along with other compounds, as the thymol concentration required to control the fungus was higher than the concentration of $L$. sidoides essential oil.

\section{CONCLUSION}

The essential oil of $L$. sidoides at a $0.2 \mu \mathrm{L} \mathrm{mL}^{-1}$ concentration and thymol at a $0.3 \mu \mathrm{L} \mathrm{mL}{ }^{-1}$ concentration are effective for in vitro control of Thielaviopsis paradoxa.

\section{REFERENCES}

1. Warwick, D. R. N.; Passos, E. E. M.; Trop. Plant Pathol. 2009, 34, 175.

2. Knaak, N.; Fiuza, L.; Neotrop. Biol. Cons. 2010, 5, 120.

3. Stangarlin, J. R.; Schwan-Estrada, K. R. F.; Cruz, M. E. S.; Nozaki, M. H.; Biotecnologia Cienc. Desenvolv. 1999, 2, 16; Bonaldo, S. M.; Schwan-Estrada, K. R. F.; Stangarlin, J.; Tessmann, D.; Scapim, C. A.; Fitopatol. Bras. 2004, 29, 128; Bastos, C. N.; Albuquerque, P. S. B.; Fitopatol. Bras. 2004, 29, 555; Knaak, N.; Fiuza, L.; Neotrop. Biol. Cons. 2010, 5, 120.
4. Schwan-Estrada, K. R. F.; Stangarlin, J. R. In Indução de resistência em plantas a patógenos e insetos; Cavalcanti, L. S.; Di Piero, R. M.; Cia, P.; Paschoati, S. F.; Resende, M. L. V.; Romeiro, R. S., eds.; FEALQ: Piracicaba, 2005, cap. 1.

5. Barrera-Necha, L. L.; Garduno-Pizana, C.; Garcia-Barrera, L. J.; Plant Pathol. J. 2009, 8, 17; Hadizadeh, I; Peivastegan, B.; Hamzehzarghani, H.; Am. J. Appl. Sci. 2009, 6, 857; Knaak, N.; Fiuza, L.; Neotrop. Biol. Cons. 2010, 5, 120.

6. Cavalcanti S. C. H.; Nicolau, E. S.; Blank, A.F.; Câmara, C. A. G.; Araújo, I. N.; Alves, P. B.; Bioresour. Technol. 2010, 101, 829.

7. Conner, D. E. In Antimicrobials and Foods; Davidson, P. M.; Branem, A. L., eds.; M. Dekker: New York, 1993, chap. 6.

8. Souza Júnior, I. T.; Sales, N. L. P.; Martins, E. R.; Biotemas 2009, 22, 77.

9. Guenther, E.; The essential oils, Krieger: Malabar, 1972.

10. Adams, R. P. Identification of essential oil components by gas chromatograpy/ quadrupopole mass spectroscopy, Allured Publishing Corporation: Illinois, 2007.

11. van den Dool, H.; Kratz, P. D. J.; J. Chromatogr. 1963, 11, 463.

12. Oliveira, O. R.; Terao, D.; Carvalho, A. C. P. P.; Innecco, R.; Albuquerque, C. C.; Rev. Ciênc. Agron. 2008, 39, 94.

13. Albuquerque. C. C.; Câmara, T. R.; Mariano, R. L. R.; Willadino, L.; Marcelino Jr., C.; Ulisses, C.; Braz. Arch. Biol. Technol. 2006, $49,527$.

14. Sikkema, J.; De Bont, J. A. M.; Poolman, B.; Physiol. Mol. Plant. Pathol. 1995, 59, 201.

15. Piper, P.; Calderon, C. O.; Hatzixanthis, K.; Mollapour, M.; Microbiology 2001, 147, 2635.

16. Montanari, R. M.; Barbosa, L. C; A. Demuner, A. J.; Silva, C. J.; Quim. Nova 2011, 34, 1550. 